\title{
PEMANFAATAN TEPUNG UBI JAAR ORANGE (IPOMOEA TRIFIDA) \\ SEBAGAI PENGGANTI SEBAGIAN JAGUNG TERHADAP PERSENTASE KARKAS, LEMAK ABDOMEN DAN ORGAN HATI AYAM KAMPUNG SUPER
}

\author{
Jeni Aturut, Martina Montong, Heidy Manangkot, Lucia Lambey
}

\author{
Fakultas Peternakan Universitas Sam Ratulangi
}

\begin{abstract}
ABSTRAK
Penelitian ini bertujuan untuk mengetahui persentase penggantian sebagian jagung dengan tepung ubi jalar orange (Ipomoea trifida) dalam ransum dan pengaruhnya terhadap persentase karkas, lemak abdomen dan organ hati ayam kampung super. Materi yang digunakan adalah ayam kampung super berumur 6 minggu sebanyak 80 ekor. Rancangan percobaan yang digunakan adalah Rancangan Acak Lengkap dengan 4 perlakuan dan 5 ulangan. Susunan perlakuan sbb: R0 Ransum tanpa menggunakan tepung ubi jalar, $\mathrm{R} 1=57,5 \%$ Jagung, 2,5\% tepung ubi jalar, R2 $=55 \%$ jagung, 5,0\% tepung ubi jalar, R3 $=52,5 \%$ Jagung, $7,5 \%$ tepung ubi jalar.Hasil penelitian menunjukkan bahwa perlakuan memberikan pengaruh berbeda nyata $(\mathrm{P}<0,05)$ terhadap persentase karkas, dimana perlakuan yang menggunakan tepung ubi jalar orange sampai dengan 7,5\% dapat meningkatkan persentase karkas, persentase lemak abdomen memberikan pengaruh yang sangat nyata $(\mathrm{P}<0,01)$ dimana semakin tinggi penggunaan tepung ubi jalar orange semakin rendah kandungan lemak abdominal ,sedangkan persentase organ hati dalam penelitian ini tidak menunjukkan perbedaan yang nyata $(\mathrm{P}>0,05)$. Berdasarkan hasil penelitian dapat disimpulkan bahwa pemanfaatan tepung ubi jalar orange dapat digunakan
\end{abstract}

*Korespondensi (Corresponding author) Email: martinamontong@gmail.com sebagai pengganti sebagian jagung sampai $7,5 \%$ dalam ransum karena dapat meningkatkan persentase karkas menekan lemak abdomen dan tidak mengganggu fungsi organ hati ternak ayam kampung Super.

Kata Kunci: Ayam kampung super, ubi jalar orange

\section{ABSTRACT}

UTILIZATION OF ORANGE SWEET POTATOES FLOUR (Ipomoea trifida) AS A SUBSTITUTE OF CORN TO THE PERCENTAGE OF CARCASS, ABDOMINAL FATS AND LIVER ORGANS OF AYAM KAMPUNG SUPER. This study aims to determine the percentage of replacement of some corn with orange sweet potato flour (Ipomoea trifida) in ration and its effect on carcass, abdominal fat and liver of super native chicken. This research used a 80 of chiken at six week old. Complete Randomized Design consist of 4 treatments and 5 replication were used as methods. The tratment were formulated as follow R0 Ration witout addition of orange sweet potatoes flour, R1 $57 \%$ corn +2.5 orange sweet potatoes flour, R2 55\% corn $+5 \%$ orange sweet potatoes flour, R3 $52.5 \%$ corn $+7.5 \%$ orange sweet potatoes flour. Research result showed that the addition of 2.5- $7.5 \%$ orange sweet potatoes flour in ration shows significant difference $(\mathrm{P}<0,05)$ on the percentage of carcass, where treatment using orange sweet potatoes flour up to $7.5 \%$ could increase the percentage of carcass. The treatment gave high 
sinificantly effect $(\mathrm{P}<0.01)$ on the percentage of abdominal fat. Percentage of liver on this research shows no sinificant effect $(\mathrm{P}>0.05)$. The conclution of this research is the giving of orange sweet potatoes can be used as substitution of corn untuil $7.5 \%$ in ration because it can increase percentage of carcass, decrease of abdominal fat percentage and does not interfere.function of liver of super native chicken.

key words: orange sweet potatoes, a super native chicken

\section{PENDAHULUAN}

Ayam kampung super saat ini menjadi peluang usaha baru yang sangat menggiurkan , karena permintaan daging ayam kampung meningkat dengan signifikan disebabkan perrmintaan konsumen yang cukup tinggi. Ayam kampung super atau ayam lokal pedaging unggul merupakan hasil persilangan antara ayam kampung dengan ayam ras, memiliki perumbuhan yang lebih cepat dibandingkan ayam kampung lokal, sehingga orang menyebutnya dengan ayam kampung super. Triswi (2016) menyatakan bahwa ayam kampung super mempunyai prtumbuhan lebih cepat daripada ayam kampung lokal. Peningkatan jumlah populasi dan tingkat produksi unggas perlu diimbangi dengan peningkatan ketersediaan pakan. Untuk mendapatkan pertumbuhan ayam yang cepat dan produktivitas tinggi diperlukan pakan yang cukup mengandung zat-zat makanan yang dibutuhkan, baik secara kualitas maupun secara kuantitas. Zat-zat makanan tersebut seperti karbohidrat, protein,lemak, mineral dan vitamin harus tersedia dalam ransum. Ransum merupakan komponen biaya terbesar sekitar $60-80 \%$ dari seluruh biaya produksi pada ternak unggas. Menekan biaya produksi sekecil mungkin tanpa mengurangi produksi optimum dapat dilakuakan dengan cara memanfaatkan bahan pakan alternatif, yang mempunyai kandungan gizi tinggi , mudah didapat dan harganya murah. Jagung merupakan bahan pakan utama yang menempati persentase tinggi dalam menyusun pakan ternak unggas, hal ini disebabkan jagung mempunyai banyak keunggulan dibandingkan pakan lainnya yakni memilik EM $3370 \mathrm{kkal} / \mathrm{g}$, protein kasar 8,6\% dan beta karotein sebesar 3,3 mg/100 gram. Ketersediaan jagung harus diperhatikan karena ketersediaannya hanya terjadi pada musim panen, sedangkan pada musim paceklik ketersediaan jagung kurang memadai oleh karena itu harganya sering berfluktuasi. Oleh karena itu perlu dicari bahan pakan alternative sebagai pengganti jagung. Salah satu pakan alternative adalah dengan memanfaatkan ubi jalar orange (Ipomoea trifena) yang mengandung energi $3530 \mathrm{Kkal}$, protein 3,34\%, Lemak 0,58\%, Kalsium (Ca) 46,9 mg/kg, fosfor (P) 672 $\mathrm{mg} / \mathrm{kg}$ dan mengandung $\beta$-Karoten 6,68 
$\mathrm{mg} / \mathrm{kg}$ (Laboratorium Analisis dan Kalibrasi Balai Besar Industri Agro, 2017). Kemajuan teknologi dan informasi memungkinkan masyarakat semakin selektif dalam memilih produk peternakan misalnya mereka menginginkan kualitas karkas yang baik. Salah satu kriteria yang digunakan konsumen adalah rendahnya proporsi lemak karkas dengan warna karkas yang menarik. Pigmentasi kulit karkas merupakan salah satu pertimbangan bagi konsumen dalam menentukan kualitas karkas ayam, karena warna karkas merupakan salah satu indikator dari kualitas karkas, meskipun tidak berpengaruh terhadap nilai gizi Berdasarkan uraian diatas maka telah dilaksanakan suatu penelitian dengan memanfaatkan ubi jalar orange sebagai pengganti sebagian jagung kuning dalam ransum terhadap kualitas karkas ayam kampung super.

\section{MATERI DAN METODE PENELITIAN}

Ternak yang digunakan dalam penelitian ini adalah ayam kampung super jantan umur 6 minggu sebanyak 80 ekor yang terbagi menjadi 4 perlakuan dan 5 ulangan, pada masing-masing ulangan terdiri dari 4 ekor. Perlakuan yang berikan R0 : Ransum dasar tanpa menggunakan tepung ubi jalar orange, R1: Ransum dengan $57,5 \%$ jagung $+2,5 \%$ tepung ubi jalar orange, R2: ransum dengan 55,0\% jagung $+5,0 \%$ tepung ubi jalar orange, R3: Ransum dengan $52,5 \%$ jagung $+7,5 \%$ Tepung ubi jalar orange.

Kandungan zat-zat makanan sebagai penyusun ransum tercantum pada Tabel 1, komposisi ransum penelitian pada Tabel 2 sedangkan komposisi zat-zat makanan ransum percobaan pada Tabel 3

Penelitian ini dilakukan di kandang percobaan Jurusan Produksi Ternak Fakultas Peternakan Universitas Sam Ratulangi Manado.

\section{Analisis Data}

Data dianalisis menggunakan analisis ragam dengan Rancangan Acak Lengkap (RAL) dilanjutkan dengan uji lanjut Beda Nyata Jujur (BNJ) menurut petunjuk Steel dan Torrie, 1990.

\section{Variable Yang Diamati}

Variable yang diamati dalam penelitian ini adalah:

Persentase Karkas

Diperoleh dari hasil perbandingan antara bobot karkas (gram) dengan bobot hidup (gram) dikalikan 100\% (North and Bell, 1990)

$$
\text { Persentase karkas }=\frac{\text { bobot karkas }}{\text { bobot hidup }} \times 100 \%
$$


Tabel 1. Kandungan Zat-zat Makanan Sebagai Penyusun Ransum

\begin{tabular}{lcccccc}
\hline Bahan Makanan & $\begin{array}{c}\text { Protein } \\
(\%)\end{array}$ & $\begin{array}{c}\text { Lemak } \\
(\%)\end{array}$ & $\begin{array}{c}\text { Serat Kasar } \\
(\%)\end{array}$ & $\begin{array}{c}\text { Ca } \\
(\%)\end{array}$ & $\begin{array}{c}\text { P } \\
(\%)\end{array}$ & $\begin{array}{c}\text { EM } \\
(\mathrm{Kkal} / \mathrm{kg})\end{array}$ \\
\hline Jagung Kuning $^{* *}$ & 9,42 & 5,17 & 2,15 & 0,22 & 0,60 & 2983,5 \\
Tepung Ubi Jalar $^{*}$ & 3,34 & 0,58 & 5,54 & 46,9 & 51 & 3530 \\
Dedak Halus $^{* *}$ & 13,44 & 6,07 & 6,35 & 0,19 & 0,73 & 2695,50 \\
Tepung Ikan $^{* *}$ & 58,52 & 2,95 & 3,90 & 7,04 & 3,67 & 3851,8 \\
Bungkil Kelapa $^{* *}$ & 24,74 & 9,36 & 15,02 & 0,11 & 0,47 & 3279,75 \\
Premiks A** & - & - & - & 32,50 & 1,00 & - \\
\hline
\end{tabular}

Sumber : * Balai Besar Industri Bogor (2017)

** Hasil analisis Laboratorium Ruminansia dan Kimia Makanan

Fakultas Peternakan Unpad, Bandung (2013)

Tabel 2. Komposisi Ransum Penelitian

\begin{tabular}{lllll}
\hline Bahan Pakan & \multicolumn{4}{c}{ Perlakuan } \\
\cline { 2 - 5 }$(\%)$ & $\mathrm{R} 0$ & $\mathrm{R} 1$ & $\mathrm{R} 2$ & $\mathrm{R} 3$ \\
\hline Jagung & 60 & 57,50 & 55 & 52,50 \\
Tepung ubi jalar & 0 & 2,50 & 5 & 7,50 \\
Dedak halus & 14,50 & 14,50 & 14,50 & 14,50 \\
Bungkil kelapa & 10 & 10 & 10 & 10 \\
Tepung ikan & 15 & 15 & 15 & 15 \\
Premix A & 0,50 & 0,50 & 0,50 & 0,50 \\
\hline Jumlah & 100 & 100 & 100 & 100 \\
\hline
\end{tabular}

Tabel 3. Komposisi Zat-zat Makanan Ransum Percobaan

\begin{tabular}{lcccc}
\hline \multicolumn{1}{c}{ Kandungan zat } & \multicolumn{4}{c}{ Perlakuan } \\
\cline { 2 - 5 } \multicolumn{1}{c}{ makanan $(\%)$} & R0 & R1 & R2 & R3 \\
\hline Protein & 18,85 & 18,70 & 18,55 & 18,39 \\
Lemak & 5,36 & 5,24 & 5,13 & 5,01 \\
Serat kasar & 4,29 & 4,38 & 4,46 & 4,54 \\
Ca & 1,39 & 2,56 & 3,72 & 4,89 \\
P & 1,07 & 2,32 & 3,59 & 4,84 \\
Energi (EM) Kkal/kg & 3086,59 & 3100,35 & 3114,01 & 3161,34 \\
\hline
\end{tabular}

Keterangan: Hasil perhitungan berdasarkan komposisi zat-zat makanan dari Tabel 1 dan Tabel 2 
Persentase Lemak Abdomen

Diperoleh dari hasil perbandingan antara bobot lemak abdomen (gram) dengan bobot hidup (gram) dikalikan 100\% (North and Bell, 1990).

Persentase lemak abdomen $=\frac{\text { bobot lemak }}{\text { bobot hidup }} \times 100 \%$

Persentase Organ Hati

Diperoleh dari perbandingan antara bobot hati (gram) dengan bobot hidup (gram) dikalikan 100\% (Mustaqim, 2006)

$$
\text { Persentase hati }=\frac{\text { bobot hati }}{\text { bobot hidup }} \times 100 \%
$$

\section{HASIL DAN PEMBAHASAN}

\section{Pengaruh Perlakuan Terhadap Persentase Karkas}

Rataan persentase karkas yang diperoleh dalam penelitian ini berdasarkan metode "Ready too cook" (tubuh ayam tanpa bulu, kepala, kaki, jeroan, kecuali hati, rempela dan jantung) menurut petunjuk North dan Bell (1990) untuk masing-masing perlakuan berkisar antara 69,19-71,67\% (Tabel 4). Persentase karkas dalam penelitian ini masih lebih tinggi dibandingkan dengan hasil penelitian yang dilakukan Mulyanto et al. (2002) evaluasi karkas ayam kampung super hasil persilangan antara ayam kampung jantan dengan ayam ras betina berkisar antara $58,87 \%-60,05 \%$. Hasil analisis keragaman menunjukan bahwa perlakuan yang diberikan memberikan pengaruh yang nyata $(\mathrm{P}<0.05)$ terhadap persentase karkas. Hasil Uji Lanjut dengan BNJ menunjukan bahawa perlakuan R1 yang menggunakan tepung ubi jalar 2,5\% menunjukan perbedaan yang nyata $(\mathrm{P}<0,05)$ dibandingkan dengan persentase karkas tanpa menggunakan tepung ubi jalar orange (RO). Sedangkan perlakuan R1, R2 dan R3 tidak menunjukkan perbedaan yang nyata $(\mathrm{P}>0,05)$. Hal ini disebabkan kandungan energi metabolis pada perlakuan R1, R2 dan R3 yang menggunakan tepung ubi jalar orange sebagai sumber energi lebih tinggi dibandingkan dengan perlakuan R0 yang menggunakan jagung sebagai sumber energy (Tabel 3). Yaman 2013 menyatakan bahwa tepung ubi jalar dapat digunakan sebagai subtitusi sebagian jagung karena kandungan energi metabolisnya cukup tinggi. Karbohidrat merupakan sumber energi untuk menunjang aktivitas ayam dan sangat dibutuhkan dalam metabolisme lemak di dalam tubuh ayam (Udjianto, 2017).

\section{Pengaruh Perlakuan Terhadap Persentase Lemak Abdomen}

Lemak abdomen merupakan merupakan indiaktor kandungan lemak karkas. Pengukuran lemak abdomen dalam penelitian ini diambil disekitar gizzard . 
Tabel 4. Rataan persentase karkas, lemak abdomen dan organ hati ayam kampung super

\begin{tabular}{lllll}
\hline \multirow{2}{*}{ Variabel } & \multicolumn{4}{c}{ Perlakuan } \\
\cline { 2 - 5 } & $\mathrm{R}_{0}$ & $\mathrm{R}_{1}$ & $\mathrm{R}_{2}$ & $\mathrm{R}_{3}$ \\
\hline Persentase Karkas (\%) & $69,19^{\mathrm{a}}$ & $71,67^{\mathrm{b}}$ & $71,30^{\mathrm{ab}}$ & $71,08^{\mathrm{ab}}$ \\
Persentase Lemak Abdomen (\%) & $1,62^{\mathrm{a}}$ & $1,29^{\mathrm{ab}}$ & $0,79^{\mathrm{bc}}$ & $0,26^{\mathrm{c}}$ \\
Persentase Organ Hati (\%) & 1,66 & 1,68 & 1,69 & 1,76 \\
\hline
\end{tabular}

Keterangan: Nilai pada baris yang sama dengan superskrip yang berbeda menunjukan perbedaan sangat nyata $(\mathrm{P}<0,05)$

Data hasil pengamatan dan perhitungan rataan persentase lemak abdomen dari masing-masing perlakuan yang diberikan selama penelitian dapat dilihat pada Tabel 4. Hasil analisis ragam dalam penelitian ini menunjukkan bahwa pemanfaatan tepung ubi jalar sebagai pengganti sebagian jagung dalam ransum memberikan pengaruh sangat nyata $(\mathrm{P}<0,01)$ terhadap persentase lemak abdomen Hasil uji lanjut dengan BNJ menunjukkan bahwa perlakuan yang menggunakan tepung ubi jalar 7,5\% dan 5\% memberikan perbedaan yang sangat nyata $(\mathrm{P}<0,01)$ terhadap persentase lemak abdomen dibandingkan dengan tanpa menggunakan tepung ubi jalar (R0) dan ransum yang menggunakan 2,5\% tepung ubi jalar (R1). Sedangkan perlakuan yang menggunakan tepug ubi jalar 5\% (R2) berbeda sangat Nyata $(\mathrm{P}<0,01)$ dibandingkan dengan perlakuan R3 yang menggunakan tepung ubi jalar 7,5\%. Hal ini mengindikasikan bahwa semakin tinggi penggunaan tepung ubi jalar sebagai penggnati sebagian jagung menurunkan persentase lemak abdomen. Rendahnya persentase lemak abdomen dalam penelitian ini disebabkan karena kandungan lemak tepung ubi jalar orange lebih rendah dibandingkan dengan kandungan lemak jagung. Hasil ini sejalan dengan hasil penelitian yang dilakukan Supratini dan Sumatrno (2010) yang menggunakan 10\% tepung ubi jalar sebagai sumber energi untuk menggantikan sebagian jagung dalam ransum ternyata dapat menurunkan persentase lemak abdomen ayam broiler. Anggorodi (1985) menyatakan bahwa energi pakan merupakan faktor penting yang dapat mempengaruhi proporsi kadar lemak karkas, karena penimbunan lemak dipengaruhi oleh komposisi ransum antara lain tingkat energi dan lemak ransum. Tsaalitsati et al. (2016) menyatakan bahwa ubi jalar orange merupakan serat larut dimana karbohidrat yang dikandungnya dalam klasifikasi Low Glycemix Index (GLI, 54) yang menyerap kelebihan 
lemak/kolesterol. Karbohidrat yang dikandung ubi jalar masuk dalam Low Glycemix Index (LGI 54) berbeda dengan Glycemix index tinggi seperti jagung. Selain itu ubi jalar orange berfungsi sebagai anti oksidan yang mampu menghalangi laju perusakan sel oleh radikal bebas (Erawati, 2006)

\section{Pengaruh Perlakuan Terhadap Persentase Organ Hati}

Data hasil pengamatan dan perhitungan rataan persentase organ hati dari masing-masing perlakuan yang diberikan selama penelitian dapat dilihat pada Tabel 1.

Organ hati yang mengalami kerusakan berat akan menjadi besar dan berwarna kuning, beratnya dapat mencapai 2-4 kali ukuran normal (Chusniati et al., 2008).

Berdasarkan hasil analisis keragaman menunjukkan bahwa perlakuan tidak memberikan pengaruh yang nyata $(\mathrm{P}>0,05)$ terhadap persentase organ hati ayam kampung super. Hal ini menunjukan bahwa pemanfaatan tepung ubi jalar orange sebagai pengganti sebagian jagung dalam ransum memberikan respons yang sama terhadap persentase organ hati. Persentase organ hati pada penelitian ini berkisar antara $1,66-1,76 \%$ (Tabel 4). Persentase organ hati normal pada ternak ayam berkisar antara 31-35 gram atau 1,70\% - 2.30\% dari bobot hidup. Hasil penelitian ini tidak jauh berbeda dengan hasil penelitian Simamora (2011), dimana prosentase organ hati ayam kampung umur 12 minggu sebesar 1,42 $1,6 \%$.

\section{KESIMPULAN}

Pemanfaatan tepung ubi jalar orange dapat digunakan sebagai pengganti sebagian jagung sampai 7,5\% dalam ransum karena dapat meningkatkan persentase karkas menekan lemak abdomen dan tidak mengganggu fungsi organ hati ternak ayam kampung super.

\section{DAFTAR PUSTAKA}

Anggorodi, 1985. Kemajuan Mutakhir Dalam Ilmu Makanan Ternak. Penerbit Universitas Indonesia Press. Jakarta

Chusniati, S., U. Huda, Sugiarti, V. Yuharni dan L. T. Suwanti. 2008. Pengaruh pemberian biji papaya (Carica papaya) terhadap gambaran histopologi hepar ayam yang diinfeksi telur cacing Ascaridia galli. Faked Unair, Journal of Poultry Diseases, Vol. 1(1)

Erawatri, C. M. 2006. Kendali Stabilitas Beta Karoten Selama Proses Produksi Tepung Ubi Jalar (Ipomoea batatas L). Tesis. Pascasarjana Institut Pertanian Bogor.

Mulyanto., P.S. Hardjosworo, R. Hermadan, H. Setijanto. 2002. 
Evaluasi karkas hasil persilangan antara ayam kampung jantan dengan ayam ras petelur betina. $\mathrm{J}$. Anim. Prod 4(2): 71-76

Mustaqim. 2006. Persentase Bobot Karkas, Organ Dalam, Dan Lemak Abdomen Broiler Yang Diberi Imbuhan Tepung Daun Sambiloto (Andrographis paniculata Nees). Skripsi. Program Studi Teknologi Produksi Ternak Fakultas Peternakan Institut Pertanian Bogor.

North dan Bell. 1990. Commercial Chicken Production manual $5^{\text {th }}$ edition Company Publishing Inc. Westport Connecticut

Steel R. G. D. and J. H. Torrie. 1990. Prinsip dan prosedur statistika (suatu pengaturan biometrika) terjemahan B. Sumantri. PT. Gramedia Jakarta.

Supratini, S. dan Sumarno 2010. Tepung ubi jalar sebagai sumber energi pakan dalam upaya peningkatan kuaitas karkas ayam pedaging. Buana Sains Vol. 10 (2): 115-120

Trisiwi, H.F. 2016. Pengaruh level protein pakan yang berbeda pada masa starter terhadap penampilan ayam kampung super. Jurnal Ilmiah Peternakan Terpadu Vol. 4(3): 256262.

Tsaalitsasati, I.I., Ishartani, D. Kawiji. 2016. Kajian sifat fisik kimia dan fungsional ubi jalar orange (Ipomoea batatas (L) Lam. Varietas Beta 2 dengan pengaruh perlakuan pengupasan umbi. Jurnal Teknosains pangan Vol V (2):

Udjianto, A. 2017. Beternak Ayam Kampung Paling Unggul. Agro Media Pustaka.
Yaman, M.A. 2013. Ayam Kampung Pedaging Unggul. Penebar Swadaya 